\title{
PEMBERDAYAAN KELOMPOK USAHA LOLOH DI DUSUN KED, DESA TARO, KABUPATEN GIANYAR
}

\author{
Putu Adi Supraptoํㅜ, I Kadek Ervan Hadi Wiryanta², I Gusti Agung Oka Sudiadnyani , Ni Luh Ayu \\ Kartika Yuniastari Sarja ${ }^{4}$, dan I Nengah Suastika \\ ${ }^{1,2,3,4}$ Politeknik Negeri Bali \\ ${ }^{5}$ Universitas Pendidikan Ganesha
}

E-mail: adisuprapto@pnb.ac.id', ervanhw@pnb.ac.id²,okasudiadnyani@pnb.ac.id ${ }^{3}$, yuniastari@pnb.ac.id ${ }^{4}$,suastikainengah85@yahoo.com ${ }^{5}$

\begin{abstract}
ABSTRAK. Kegiatan pengabdian kepada masyarakat seyogyanya senantiasa besinergi dengan masyarakat dengan potensi yang cukup besar akan tetapi masih kurang optimal dari segi operasionalnya. Usaha loloh/jamu di Dusun Ked, Desa Taro, Kecamatan Tegalalang berdiri tahun 2004. Pemilik usaha ini adalah I Wayan Kariasa. Walaupun sudah berdiri cukup lama, namun dari segi omset penjualan, cakupan wilayah pemasaran dan penjualan produk, tata kelola usaha dan keuntungan relatif kecil dan tidak berkembang pesat dari awal berdirinya sampai sekarang. Kendala yang dihadapi adalah keterbatasan peralatan kerja, pemasaran dan perhitungan omset usaha. Kegiatan diawali dengan sosialiasasi kepada anggota kelompok usaha loloh dan pemberian sosialisasi aspek Kesehatan dan Keselamatan Kerja (K3). Kegiatan yang telah dilakukan adalah memberikan bantuan alat-alat untuk peralatan kerja seperti: Mesin Penggiling Rempah, Alat Pengangkut, Kompor Besar dan Mesin Pendingin yang digunakan dalam proses produksi loloh. Selain itu, kegiatan lain yang telah dilakukan adalah membantu dalam desain kemasan agar lebih menarik dan mudah dikenal konsumen. Indikator capaian kegiatan adalah terwujudnya usaha loloh yang berdaya saing, hegienis, mudah dikenal, dengan pangsa pasar yang lebih luas dan produk yang bernilai ekonomi tinggi. Dengan kegiatan yang telah dilakukan, kelompok usaha loloh mampu meningkatkan produksi produk dan pendapatan hingga $60 \%$ per bulan. Pada akhir kegiatan tim pengabdian telah memberikan pelatihan keuangan sederhana guna mengetahui omset penjualan produk per bulannya.
\end{abstract}

Kata kunci: Pemberdayaan; Kelompok Usaha Loloh; Desain Produk

ABSTRACT. Community service activities should always synergize with communities with considerable potential but are still less than optimal in terms of operations. The loloh / herbal medicine business in Ked Hamlet, Taro Village, Tegalalang District was established in 2004. The owner of this business is I Wayan Kariasa. Even though it has been around for a long time, in terms of sales turnover, the scope of marketing and product sales, business governance and profits are relatively small and did not develop rapidly from its inception until now. Constraints faced are limited work equipment, marketing and business turnover calculations. The activity began with socialization to the members of the loloh business group and the dissemination of aspects of Occupational Health and Safety. Activities that have been carried out are providing assistance for tools for work equipment suchas: Spice Grinders, Transport Equipment, Large Stoves and Cooling Machines used in the loloh production process. In addition, other activities that have been carried out are assisting in the design of packaging to make it more attractive and easily known to consumers. The activity achievement indicator is the realization of a competitive, hygienic, easily recognized loloh business, with a wider market share and products of high economic value. With the activities that have been carried out, the loloh business group is able to increase product production and income by up to $60 \%$ per month. At the end of the activity the service team has provided simple financial training to find out the monthly product sales turnover.

Key words: Empowerment; Loloh Business Group; Product Design

\section{PENDAHULUAN}

Bali sebagai salah satu destenasi terbaik wisatawan dikenal memiliki banyak kearifan local/local genius. Mulai dari seni, budaya, nilai sosio religious, kue, makanan dan minuman khas Bali senantiasa menjadi sebuah potensi yang mampu dikemas menjadi produk yang bernilai ekonomi yang tinggi. Hal ini yang mendorong muncul dan menjamurnya pasar oleh-oleh khas Bali yang menjual berbagai jenis produk khas Bali.

Saat ini kearifan lokal berupa minuman khas Bali masih bisa dijumpai dan digemari serta dijadikan sarana upacara keagamaan oleh masyarakat Bali, seperti: kopi Bali, teh Bali, daluman, tuak, arak Bali, loloh dan berem. Sebagai salah satu kearifan lokal yang ada di Bali, loloh Bali terkenal memberikan kesegaran dan memiliki suatu kasiat bagi orang yang mengkonsumsinya. Jamu adalah sebutan untuk obat tradisional dari Indonesia.
Belakangan populer dengan sebutan herba atau herbal. Jamu biasanya terasa pahit sehingga perlu ditambah madu sebagai pemanis agar rasanya lebih dapat ditoleransi peminumnya. Bahkan ada pula jamu yang ditambah dengan anggur. Selain sebagai pengurang rasa pahit, anggur juga berfungsi untuk menghangatkan tubuh.

Loloh dibuat dari bahan-bahan alami, berupa bagian dari tumbuhan seperti rimpang (akar-akaran), daundaunan, kulit batang, dan buah. Ada juga menggunakan bahan dari tubuh hewan, seperti empedu kambing, empedu ular, atau tangkur buaya. Seringkali kuning telur ayam kampung juga dipergunakan untuk tambahan campuran pada loloh/jamu. Sebagai minuman yang memiliki kasiat tersendiri dan baik untuk kesehatan, loloh merupakan minuman yang menjadi favorit masyarakat Bali dan Indonesia pada umumnya.

Sebagai salah satu destinasi Pariwisata di wisatawan manca Negara, membuat pelaku Pariwisata di Bali 
senantiasa melakukan inovasi dan langkah strategis dalam mengemas produk pariwisata untuk dapat dinikmati oleh masyarakat Bali. Tidak jarang wisatawan yang berkujung ke Bali tersebut meminta dan dimintan untuk mencoba menkonsumsi loloh/jamu. Bahkan berdasarkan observasi tim pengabdian, di salah satu Resort yang ada di Kawasan Ubud, Kabupaten Gianyar, yaitu tepatnya di The Ubud Village Resort \& Spa. Di resort tersebut menggunakan loloh yang terbuat dari bahan alami seperti daun "PiduhPiduh" yang dicampur dengan daun mint, air perasan jeruk nipis, diisi gula batu dan air putih yang dijadikan welcome drink mereka.

Sentra kelompok usaha loloh di Provinsi Bali ada di Kabupaten Bangli, tepatnya di daerah Penglipuran. Loloh cencem saat ini sudah semakin dikenal dan tersedia dengan mudah di kios, warung dan pasar yang ada di Bali. Kelompok usaha loloh cemcem pun saat ini semakin bertambah dan berkembang. Tentunya ini didukung fakta adanya peningkatan konsumsi masyarakat Bali terhadap loloh tersebut. Pangsa pasar yang bergeliat ini tentunya harus dibarengi dengan peningkatan kualitas dan kuantitas produksi loloh.

Berbeda dengan loloh cemcem yang diproduksi di daerah Penglipuran, di Dusun Desa Taro, Kecamatan Tegalalang, Kabupaten Gianyar memiliki kelompok usaha yang memproduksi Loloh Kunyit. Kelompok usaha yang dikoordinir oleh I Wayan Kariasa yang beranggotakan 3 (tiga) orang memulai usaha loloh kunyit ini pada awal Tahun 2004. Dalam perkembangannya sampai sekarang, keberadaan kelompok usaha ini memang ada perkembangan akan tetapi belum maksimal.

Beberapa kendala dan permasalahan yang saat ini sedang dihadapi oleh kelompok usaha loloh ini. Mulai dari proses produksi yang tidak didukung dengan peralatan standar dan memadai seperti parutan dan saringan sehingga membutuhkan waktu yang cukup lama dalam proses produksi, kualitas loloh kunyit yang dihasilkan tidak bisa tahan lebih dari 2 (dua) hari sehingga potensi untuk busuk ( kurang lebih 10\%) karena tidak terjual sangat tinggi dikarenakan tidak disimpan pada tempat pendingin. Selain itu pengemasan produk loloh yang belum ada dan sulit untuk dikenal, pemasaran produk yang relatif tidak berkembang dan belum memperhatikan aspek K3 dan perhitungan omset usaha. Dari segi rasa dan kasiat loloh kunyit yang dihasilkan oleh kelompok usaha "Bli Sabar" sangat menyegarkan dan dipercaya memiliki kasiat bagi yang meminumnya.

Tujuan dari kegiatan ini adalah:

1. Mewujudkan proses produksi loloh kunyit yang memperhatikan aspek K3 guna menciptakan keamanan dan kehieginisan produk;

2. Mewujudkan proses produksi yang didukung dengan peralatan standar dan memadai.

3. Mewujudkan kualitas loloh kunyit yang dihasilkan bisa tahan lama, hal ini tentunya sangat dipengaruhi oleh bantuan mesin pendingin yang diberikan oleh tim pengabdian.
4. Mewujudkan produk loloh kunyit "Bli Sabar" dengan kemasan menarik, mudah dikenal dan dengan berbagai varian rasa dan ukuran.

5. Mewujudkan pemasaran loloh kunyit "Bli Sabar" ke pangsa pasar yang lebih luas, khususnya di Kabupaten Gianyar, dan Provinsi Bali pada umumnya.

6. Mewujudkan laporan keuangan sederhana yang dicatat secara periodik, selama minimal 1 (satu) tahun sekali.

Dampak dari kegiatan ini diharapkan adanya peningkatan profesionalisme usaha dan pendapatan dari kelompok usaha binaan.

\section{METODE}

Adapun prosedur kerja dari kegiatan ini dilaksanakan melalui 5 (lima) langkah kerja, yang akan dimulai dari sosialisasi, memberikan pemahaman dan pengetahuan terkait aspek K3 dalam proses produksi, mendesain label kemasan produk, Diversifikasi varian rasa loloh, bantuan alat-alat produksi dan Pelatihan Penyusunan Buku Pencatat Transaksi Keuangan.

Berdasarkan permasalahan prioritas yang sedang dihadapi, adapun beberapa solusi yang ditawarkan adalah sebagai berikut:

1. Mewujudkan proses produksi loloh kunyit yang memperhatikan aspek K3 guna menciptakan keamanan dan kehieginisan produk;

2. Mewujudkan proses produksi yang didukung dengan peralatan standar dan memadai. Kegiatan ini memberikan bantuan alat-alat produksi, sehingga ada beberapa tahapan dari produksi akan menggunakan alat-alat produksi modern tanpa menghilangkan cara-cara tradisional yang sudah ada. Sebagai contoh penghalusan rempah-rempah sebagai bahan baku loloh akan menggunakan mesin penghalus yang berasal dari bantuan alat kegiatan ini. Dengan peralatan yang memadai maka akan meningkatkan proses produksi dan pendapatan mitra kegiatan.

3. Mewujudkan kualitas loloh kunyit yang dihasilkan bisa tahan lama, hal ini tentunya sangat dipengaruhi oleh bantuan mesin pendingin. Dengan diletakkan pada mesin pendingin, loloh kunyit akan awet atau tahan lama, hingga 7 (tujuh) hari. Sehingga potensi kerugian dengan adanya busuk produk yang lebih dari 2 (dua) hari akan di minimalisir.

4. Mewujudkan produk loloh kunyit "Bli Sabar" dengan kemasan menarik, mudah dikenal dan dengan berbagai varian rasa. Begitu juga dari varian produk tidak hanya dengan botol isi $330 \mathrm{ml}$, tapi juga ada yang $700 \mathrm{ml}$ agar sesuai keinginan pasar.

5. Mewujudkan pemasaran loloh kunyit "Bli Sabar" ke pangsa pasar yang lebih luas, khususnya di Kabupaten Gianyar, dan Provinsi Bali pada umumnya.

6. Mewujudkan laporan keuangan sederhana yang dicatat secara periodik, selama minimal 1 (satu) tahun 
sekali. Diharapkan dengan hal tersebut, mitra mampu menghitung jumlah omset usahanyara

Upaya yang dilakukan untuk mengatasi permasalahan yang dihadapi antara lain:

a. Memberikan pemahaman dan pengetahuan terkait kegiatan ini melalui proses/kegiatan sosialisasi;

b. Memberikan pemahaman dan pengetahuan terkait aspek Kesehatan dan Keselamatan Kerja (K3) dalam proses produksi loloh oleh mitra kegiatan;

c. Membuat desain kemasan produk mitra agar lebih menjual dan mudah dikenal oleh konsumen serta memiliki pangsa pasar yang lebih luas;

d. Membuat varian rasa loloh selain berbahan baku kunyit, sehingga memiliki beberapa pilihan rasa bagi konsumen;

e. Memberikan pelatihan keuangan laba rugi bagi keberadaan usaha loloh yang selama ini masih belum ada laporan keuangannya.

\section{HASIL DAN PEMBAHASAN}

Tahap pertama yang dilakukan adalah melaksanakan survey dan penjajakan lokasi. Setelah kegiatan survey dan penjajakan dilakukan, kegiatan dilanjutkan dengan kegiatan sosialisasi atau pengarahan kepada mitra terkait kegiatan Pengabdian kepada Masyarakat (PkM) di Dusun Ked, Desa Taro, Kecamatan Tegalalang, Gianyar. Kegiatan sosialisasi ini memberikan pemahaman yang mendetail dan menyeluruh terkait latar belakang, identifikasi masalah, solusi, target, sasaran dan tujuan kegiatan ini. Dari sosialisasi ini juga dicapai kesimpulan bahwa dengan kegiatan ini, diharapkan mitra mampu meningkatkan produktivitas usaha yang memberi dampak nyata pada pendapatan dari mitra kegiatan itu sendiri. Tentunya dampak tersebut akan direncanakan dan dikembangkan secara bertahap dan berkesinambungan.

1. Pemahaman dan Pengetahuan Terkait Aspek K3 dalam Proses Produksi Loloh oleh Mitra Kegiatan Keselamatan dan Kesehatan Kerja (K3) merupakan sistem yang di dalamnya memiliki nilai perlindungan terhadap pekerja dari potensi bahaya serta kecelakaan atau penyakit akibat kerja (Alamsyah, 2013). K3 merupakan ilmu pengetahuan dan penerapannya dalam upaya mencegah terjadinya kecelakaan dan menjamin aspek kesehatan dalam bekerja. Kesehatan Keselamatan Kerja (K3) tidak dapat dipisahkan dengan proses produksi baik jasa maupun industri. Saat ini usaha kecil, mikro dan menengah yang bergerak pada bidang makanan dan minuman sudah mulai menerapkan aspek K3 untuk proses produksi seperti yang dilakukan pada UKM Roti (Ginting, $\mathrm{dkk}, 2016$ ) dan industri tahu serta minuman (Artiyani, A. dan Sujianto, 2008). Dalam kegiatan yang telah dilaksanakan pada mitra disini adalah aspek K3 yang sederhana. Tujuan kegiatan ini adalah menciptakan kehieginisan dalam pengemasan produk mitra. Di awal kegiatan ini diselenggarakan, mitra kegiatan ini hanya menggunakan botol bekas air mineral yang diperoleh dari para pengepul botol bekas dan perusahaan yang menghasilkan sampah botol air mineral yang cukup banyak seperti usaha agrotourism. Hal ini dilakukan karena harga yang diperoleh relatif lebih murah dibandingkan membeli botol baru. Akan tetapi setelah memperoleh penyuluhan aspek K3 dari tim k tidak lagi menggunakan botol air mineral bekas. Lebih lanjut, untuk aspek K3 lain khususnya dalam produksi dan pengemasan produk mitra sudah dilaksanakan dengan standar minimal yang harus diperhatikan, seperti menggunakan masker dan slop tangan.

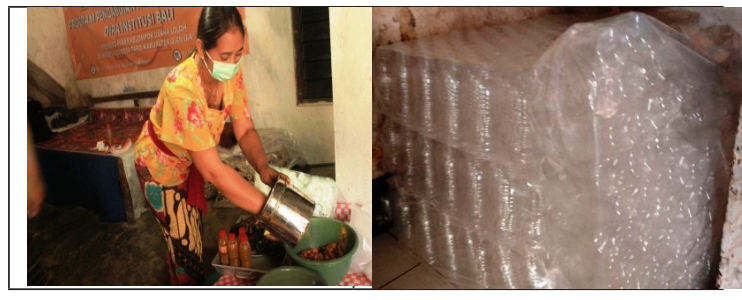

Gambar 1. Penerapan Aspek K3 pada Proses Produksi Loloh

2. Desain Kemasan Produk Mitra

Tahapan kegiatan yang dilakukan selanjutnya adalah membuat desain kemasan produk mitra agar lebih menjual dan mudah dikenal oleh konsumen serta memiliki pangsa pasar yang lebih luas. Tim membuatkan desain bagi mitra kegiatan. Selama ini produk mitra belum memiliki desain yang menarik dan mampu dikenal. Dengan keberadaan produk loloh kunyit yang ada di pasaran relatif banyak dan sama, maka harus dibuatkan desain yang relatif berbeda untuk memberikan identitas bagi keberadaan produk mitra. Kegiatan ini diawali dengan menyusun desain produk yang dikoordinasikan antara tim pelaksana dengan mitra kegiatan. Penyusunan desain dilaksanakan dengan aplikasi komputer dan dilakukan finalisasi sebelum dicetak.

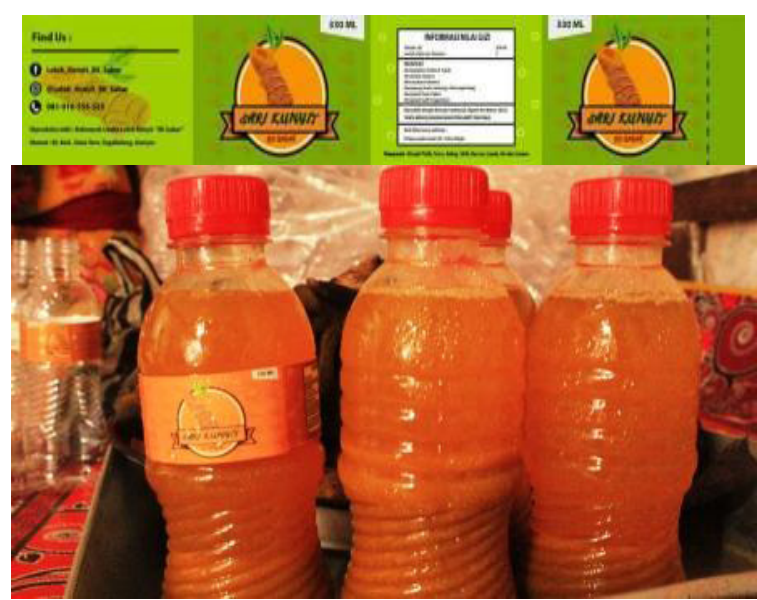

Gambar 2. Proses Pembuatan Desain Kemasan Produk Mitra 
3. Membuat Varian Rasa Loloh selain Berbahan Baku Kunyit

Tahapan kegiatan selanjutnya yang dilaksanakan adalah membuat varian rasa baru. Varian rasa yang dikembangkan pada tahapan kegiatan ini merupakan varian rasa yang bersumber pada potensi yang ada pada Dusun Ked, Desa Taro. Dengan dibantu oleh masyarakat di Dusun Ked, tim pengabdian dan mitra kegiatan melakukan observasi terkait potensi yang dapat dikembangkan dari daerah tempat tinggal mitra. Berdasarkan proses diskusi dan observasi tim pelaksana dengan pihak terkait, maka diperoleh kesepakatan untuk membuat varian rasa loloh baru yang bahan baku dasarnya adalah daun ter-teran. Hal ini sangat didukung dengan fakta bahwa bahan baku pohon terteran sangat mudah dijumpai di lokasi mitra kegiatan. Kegiatan pada tahapan ini kemudian dilanjutkan dengan melakukan pengolahan terhadap bahan baku dari varian rasa baru loloh yang diberi nama loloh don ter-teran. Dengan menambahkan bahan berupa lunak, garam, air dan gula batu. Mitra kegiatan mencoba untuk melakukan produksi loloh tersebut. Dalam hal pengelolaannya memang relatif sama dengan pengolahan loloh kunyit, dengan perbedaan pada proses perebusan, yang tidak termasuk daunnya dan larutannya. Kasiat dari loloh ini juga sangat baik untuk penyembuhan panas dalam, memperlancar metabolism tubuh dan tentunya memberikan kesegaran tersendiri. Pada akhirnya mitra mampu memproduksi loloh daun ter-teran ini dan memproduksinya dan dijual pada khalayak umum. Loloh daun ter-teran ini bisa bertahan sampai 7 hari jika disimpan pada lemari pendingin.

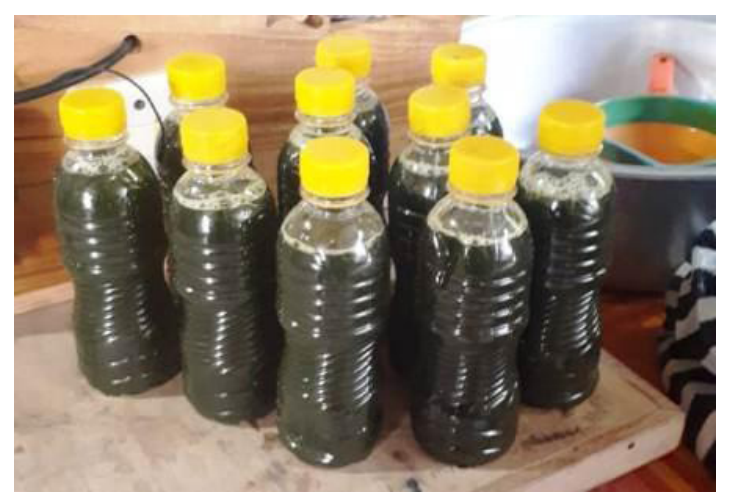

Gambar 3. Loloh daun ter-teran

4. Penyerahan Bantuan Alat-Alat Produksi kepada Mitra Kegiatan

Serangkaian kegiatan pada tahapan-tahapan kegiatan di Dusun Ked, Desa Taro, Kecamatan Tegalalang, Kabupaten Gianyar ini telah dilaksanakan dengan jadwal kegiatan yang telah ditetapkan. Namun demikian dari serangkaian kegiatan yang telah dan akan dilaksanakan, kegiatan pembuatan alat-alat produksi yang disesuaikan dengan perkembangan ipteks guna membantu dan mengoptimalkan proses produksi dan pemasaran produk mitra dapat dikatakan sebagai inti atau esensi dari serangkaian kegiatan Pengabdian kepada Masyarakat ini. Tim Pengabdian melakukan koordinasi dalam membuat alat-alat produksi seperti mesin penghancur bumbu-bumbu atau rempah-rempah bahan baku dari loloh kunyit dan loloh don ter-teran. Hal ini dilaksanakan guna membantu mitra kegiatan untuk menghemat waktu dan tenaga mereka dalam melakukan proses produksi. Begitu juga dalam hal penyusunan desain kemasan yang selama ini memang dirasa belum mendapat perhatian dari mitra kegiatan. Sehingga dapat dikatakan nantinya mitra kegiatan mampu berdaya saing dan mendapatkan identitas tersendiri yang dapat dikenal kalayak umum. Rentan waktu pelaksanaan kegiatan Persiapan Pembuatan Alat-alat Produksi bagi Mitra dan Pembuatan Desain Kemasan Produk Mitra adalah dari tanggal 03 Juni 2019 sampai tanggal 15 Juli 2019

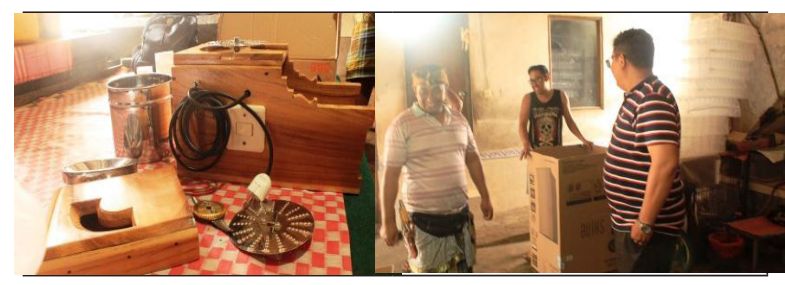

Gambar 4. Bantuan peralatan produksi

5. Penyerahan dan Pelatihan Penyusunan Buku Pencatat Transaksi Keuangan

Penyerahan Buku Pencatat Transaksi Keuangan kepada mitra direncakan telah dilakukan dengan kegiatan pelatihan manajemen keuangan mitra. Mitra sangat tertarik dengan proses pelatihan ini dan Tim Pengabdian sudah memberikan pelatihan sederhana dan mudah dipahami olehpesertapelatihan. Dalam kegiatan ini sudah diberikan buku kas yang bertujuan untuk memudahkan mitra dalam mencatat setiap transaksi keuangan yang dilakukannya sehingga nantinya dapat mengukur nilai keuntungan atau omset mitra setiap bulannya. Selama ini mitra kegiatan masih tidak memperhatikan aspek ini.

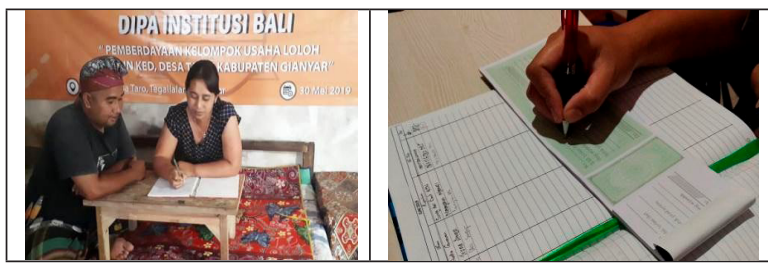

Gambar 5. Proses Pelatihan Penyusunan Buku Pencatat Transaksi Keuangan

6. Evaluasi Kegiatan

Evaluasi kegiatan dilakukan setelah diselesaikannya semua kegiatan. Berdasarkan hasil evaluasi dapat disimpulkan bahwa terdapat peningkatan pengetahuan mitra terkait K3, labeling kemasan dan manajemen keuangan. Hal ini didapatkan berdasarkan hasil wawancara. Selain 
itu dapat disimpulkan pula bahwa kegiatan pengabdian ini telah sesuai dengan rencana dan target yang telah ditetapkan.

\section{SIMPULAN}

Berdasarkan kegiatan yang telah dilakukan sampai saat ini maka diperoleh beberapa kesimpulan, yaitu: Bahwa kegiatan yang telah dilakukan secara menyeluruh sesuai rencana kegiatan yang telah ditetapkan diawal. Adapun kegiatan yang dimaksud antara lain: Memberikan Sosialisasi Kegiatan; Memberikan Pemahaman dan Pengetahuan Terkait Aspek K3 dalam Proses Produksi Loloh oleh Mitra Kegiatan; Membuat Desain Kemasan Produk Mitra; Membuat Varian Rasa Loloh selain Berbahan Baku Kunyit; dan Penyerahan Bantuan Alat-Alat Produksi kepada Mitra Kegiatan; Finalisasi Realisasi Usaha Loloh yang Memiliki Pangsa Pasar Lebih Luas; Penyerahan dan Pelatihan Penyusunan Buku Pencatat Transaksi Keuangan; Penyelesaian Pembuatan Laporan Kegiatan; dan Publikasi Ilmiah Hasil Kegiatan; Kegiatan ini secara spesifik tentunya adalah sebuah upaya peningkatan dan pemberdayaan masyarakat, khususnya untuk UMKM. Berdasarkan hasil evaluasi yang telah dilakukan dengan membandingkan jumlah produksi sebelum dan setelah kegiatan, usaha loloh mampu meningkatkan produksi produk dan pendapatan sebanyak $60 \%$ (enam puluh persen) per bulan.

\section{UCAPAN TERIMAKASIH}

Terima kasih kepada Direktorat Riset dan Pengabdian Masyarakat, Direktorat Jenderal Penguatan Riset dan Pengembangan Kementerian Riset Teknologi dan Pendidikan Tinggi Republik Indonesia dan Politeknik Negeri Bali yang telah memberikan kesempatan kepada kami untuk mendapatkan bantuan pendanaan kegiatan Pengabdian kepada Masyarakat ini.

\section{DAFTAR PUSTAKA}

Alamsyah, D., Muliawarti, R. 2013. Pilar Dasar Ilmu Kesehatan Masyarakat. Nuha Medika: Yogyakarta.

Artiyani, A., Sujianto. 2008. Upaya Kesehatan dan Keselamatan Kerja pada Industri Kecil di Kota Malang. Jurnal Specttra. 6(11), pp.22-33.

Ginting, R., Tarigan, U., Sitorus, E. 2016. Perbaikan Proses Produksi Ukm Roti Di Kota Medan Melalui Penerapan Disiplin Teknik Industri. Jurnal Sistem Teknik Industri. 18(2), pp 95100 . 